\title{
Vitamin D and the epigenome
}

\section{Irfete S. Fetahu, Julia Höbaus and Enikö Kállay*}

Department of Pathophysiology and Allergy Research, Center of Pathophysiology, Infectiology and Immunology, Comprehensive Cancer Center, Medical University of Vienna, Vienna, Austria

Edited by:

Carsten Carlberg, University of

Eastern Finland, Finland

Reviewed by:

Patsie Polly, The University of New South Wales, Australia

Moray J. Campbell, Roswell Park

Cancer Institute, USA

\section{*Correspondence:}

Enikö Kállay, Department of

Pathophysiology and Allergy

Research, Medical University of

Vienna, Währinger Gürtel 18-20,

A-1090 Vienna, Austria

e-mail: enikoe.kallay@

meduniwien.ac.at
Epigenetic mechanisms play a crucial role in regulating gene expression. The main mechanisms involve methylation of DNA and covalent modifications of histones by methylation, acetylation, phosphorylation, or ubiquitination. The complex interplay of different epigenetic mechanisms is mediated by enzymes acting in the nucleus. Modifications in DNA methylation are performed mainly by DNA methyltransferases (DNMTs) and ten-eleven translocation (TET) proteins, while a plethora of enzymes, such as histone acetyltransferases (HATs), histone deacetylases (HDACs), histone methyltransferases (HMTs), and histone demethylases (HDMs) regulate covalent histone modifications. In many diseases, such as cancer, the epigenetic regulatory system is often disturbed. Vitamin D interacts with the epigenome on multiple levels. Firstly, critical genes in the vitamin $D$ signaling system, such as those coding for vitamin $D$ receptor (VDR) and the enzymes 25-hydroxylase (CYP2R1), 1 $\alpha$-hydroxylase (CYP27B1), and 24-hydroxylase (CYP24A1) have large CpG islands in their promoter regions and therefore can be silenced by DNA methylation. Secondly, VDR protein physically interacts with coactivator and corepressor proteins, which in turn are in contact with chromatin modifiers, such as HATs, HDACs, HMTs, and with chromatin remodelers. Thirdly, a number of genes encoding for chromatin modifiers and remodelers, such as HDMs of the Jumonji C (JmjC)-domain containing proteins and lysine-specific demethylase (LSD) families are primary targets of VDR and its ligands. Finally, there is evidence that certain VDR ligands have DNA demethylating effects. In this review we will discuss regulation of the vitamin D system by epigenetic modifications and how vitamin $D$ contributes to the maintenance of the epigenome, and evaluate its impact in health and disease.

Keywords: VDR, VDRE, 1,25-dihydroxyvitamin D3, CYP27B1, CYP24A1, DNA methylation, histone modifications, CpG island

\section{INTRODUCTION}

The role of vitamin $\mathrm{D}$ in regulating gene expression has become increasingly evident since the discovery of the transcription factor vitamin D receptor (VDR), a member of the steroid nuclear receptor superfamily. The effect of liganded VDR depends on the epigenetic landscape of the target gene. Genome wide analysis in the human leukemia cell line THP-1 showed that VDR binds mainly at loci of open chromatin. Upon treatment with the VDR ligand 1,25-dihydroxyvitamin $\mathrm{D}_{3}\left(1,25-\mathrm{D}_{3}\right)$, chromatin accessibility further increases in more than $30 \%$ of these loci (Seuter et al., 2013). The mechanism of action of the liganded VDR is dependent on binding and action of histone acetyltransferases (HATs) and histone methyltransferases (HMTs). It has been shown that co-treatment of cells with $1,25-\mathrm{D}_{3}$, and histone deacetylase or DNA methyltransferase inhibitors often have synergistic effects (Pan et al., 2010).

Many common diseases have both genetic and epigenetic components, which communicate in an intricate and multilayered manner. Currently, it is not clear to what extent epigenetic alterations contribute to onset and progress of common diseases, such as cancer. Epigenetics refers to processes that alter gene activity without changing the DNA sequence. They play an important role in regulating key processes during development, including embryonic developmental events, gene imprinting, and inactivation of chromosome $\mathrm{X}$ in females (Bird, 2002; Meissner et al., 2008; Tsai and Baylin, 2011). Maintenance of normal functioning of these biological processes is dependent on the intricate interaction between several epigenetic mechanisms, such as DNA methylation, histone modifications, and non-coding RNAs (Jones and Baylin, 2007). Therefore, at a given promoter the marks arising from DNA methylation and histone modifications determine whether the chromatin is in an open (active) or a closed (repressed) state. Deregulation of the epigenetic mechanisms can lead to aberrant DNA methylation patterns and chromatin architecture, which is a common feature in cancer (Baylin and Jones, 2011; Tsai and Baylin, 2011; Helin and Dhanak, 2013).

\section{EPIGENETIC CHANGES MEDIATED BY THE VITAMIN D RECEPTOR AND ITS LIGANDS}

The effect of nutrition on the methylation equilibrium of the genome is already accepted as one of the mechanisms preventing either promoter hyper- or global hypomethylation. Several nutrients are renowned for their impact on DNA methylation, such as folic acid, vitamin B, green tea, and alcohol (Arasaradnam et al., 2008). The effect of vitamin D is currently under debate.

Primary epigenetic effects of vitamin D are linked to histone modifications, mainly acetylation. The VDR/RXR dimer interacts with HATs to induce transcriptional activation (Karlic and Varga, 
2011). Several studies have suggested that vitamin D may affect also DNA methylation. A recent study associated severe vitamin D deficiency with methylation changes in leukocyte DNA, although the observed differences were relatively small (Zhu et al., 2013). This study suggested that subjects with vitamin D deficiency were more likely to show reduced synthesis and increased catabolism of active vitamin D. Whether this was the cause of the vitamin $\mathrm{D}$ deficiency or the consequence thereof is not clear and needs further studies.

\section{EFFECT OF VITAMIN D ON DNA METHYLATION}

DNA methylation is the most extensively studied epigenetic mark (Esteller, 2008). In humans, DNA methylation occurs on cytosines followed by guanine (CpG) (Bird, 1980; Gruenbaum et al., 1981). Regions of DNA enriched in CpG clusters form CpG islands (CGI) (Wang and Leung, 2004). DNA methylation is necessary for regulating and orchestrating key biological processes, including cell cycle, differentiation, as well as genomic imprinting (Feinberg et al., 2002; Reik and Lewis, 2005; Jones and Baylin, 2007). DNA hypermethylation is mainly found in intergenic regions and repetitive genomic sequences to maintain these in a transcriptionally inactive chromatin state (Herman and Baylin, 2003).

DNA methyltransferases (DNMTs) mediate DNA methylation (Robertson, 2005). DNMT1 encodes for a maintenance methyltransferase, whereas DNTM3A/3B encode for de novo methyltransferases, which are pivotal to maintain and establish genomic methylation (Okano et al., 1998, 1999; Jin and Robertson, 2013). However, in vivo studies suggest that all three DNMTs might exert both de novo and maintenance functions (Rhee et al., 2000, 2002; Kim et al., 2002; Esteller, 2007a). Recently, a new group of enzymes that induce active demethylation of the DNA was discovered, the ten-eleven translocation (TET) enzyme family, which plays an important role both in development and tumorigenesis (Kriaucionis and Heintz, 2009; Ficz et al., 2011; Williams et al., 2011; Yamaguchi et al., 2012; Hackett et al., 2013).

Alterations in the cancer epigenome are generally associated with loss of global DNA methylation and gain of methylation in specific gene promoters (Ting et al., 2006). Loss of global methylation may lead to chromosomal instability (Eden et al., 2003), loss of imprinting (Cui et al., 2003; Bjornsson et al., 2007), and activation of transposable elements, thereby leading to disturbances in the genome (Bestor, 2005; Esteller, 2008). Conversely, hypermethylation of promoter regions of tumor suppressor genes (Greger et al., 1989; Sakai et al., 1991; Esteller, 2008) leads to loss of expression of key genes affecting pathways involved in maintenance of cellular functions, including cell cycle, apoptosis, and DNA repair (Esteller, 2007b). Several bona fide tumor suppressor genes are silenced by promoter hypermethylation in tumors. For instance, hypermethylation of the promoter of the DNA repair gene $h M L H 1$ is associated with early stages of endometrial and colon cancer, and microsatellite instability phenotype (Esteller et al., 1999). Epigenetically mediated silencing of cyclin-dependent kinase inhibitor $2 \mathrm{~A}$, which is crucial for control of cell cycle has been reported in several cancers (Brock et al., 2008; Liau et al., 2014). Additionally, pathways regulated by microRNAs have been associated with DNA hypermethylation-dependent silencing (Saito et al., 2006).

Besides methylating cytosines, DNMTs may coordinate other chromatin-mediated aspects of gene expression at sites of gene promoters (Herman and Baylin, 2003). For example, hypermethylation of promoters of tumor suppressor genes is associated with recruitment of proteins belonging to the methyl CpG-binding domain (MBD) family, MeCP2, MBD1, MBD2, MBD3, and MBD4 (Ballestar and Esteller, 2005). It has been shown that $\mathrm{MeCP} 2$ represses transcription of methylated DNA by recruiting histone deacetylases (HDACs), providing the first evidence for interactions between DNA methylation and histone modifications (Jones et al., 1998; Nan et al., 1998).

There is evidence that $1,25-\mathrm{D}_{3}$ is able to induce DNA demethylation, however, the mechanisms behind the effect of $1,25-\mathrm{D}_{3}$ on DNA methylation are not clear. In most cases it is probably passive demethylation that happens over several cycles of DNA replication. However, in some cases demethylation occurs within 1-4 h, indicative of an active process (Doig et al., 2013). The fact that vitamin $\mathrm{D}$ can alter methylation of DNA in the promoter of certain genes is novel. Tapp and colleagues suggested that in healthy subjects global, age-related CGI methylation of human rectal mucosa was influenced not only by gender, folate availability, and selenium, but also by vitamin $D$ status (Tapp et al., 2013). The authors show negative association between serum $25-\mathrm{D}_{3}$ level and CGI methylation of the adenomatous polyposis coli $(A P C)$ promoter region, a tumor suppressor often inactive in colorectal cancer. Interestingly, they observed a weak positive correlation of vitamin $\mathrm{D}$ level with methylation of LINE-1 (genomic long interspersed nuclear element-1), a mammalian autonomous retrotransposon, increasing stability of this region (Tapp et al., 2013). A recent study in colorectal cancer patients investigating two Canadian populations (from Newfoundland and Ontario) found that high dietary vitamin D intake was associated with lower methylation of the two WNT antagonists dickkopf 1 (DKK1) and WNT5A (Rawson et al., 2012). This relationship became even more significant in females in the Newfoundland population, while in the Ontario population the association between vitamin $\mathrm{D}$ intake and lower methylation was observed only in early stage tumors, but not in late stage tumors (Rawson et al., 2012). These data confer further insights in the mechanisms regulating the transcriptional activating effect of vitamin $\mathrm{D}$ on $D K K 1$ expression described in vitro (Aguilera et al., 2007; Pendas-Franco et al., 2008).

Moreover, treatment of the triple negative breast cancer cell line MDA-MB-231 with $1,25-\mathrm{D}_{3}$ reduced DNA methylation of the e-cadherin promoter (Lopes et al., 2012), while another study showed that $1,25-\mathrm{D}_{3}$ induced demethylation of the PDZLIM domain-containing protein 2 promoter, leading to increased expression (Vanoirbeek et al., 2014). In non-malignant and malignant prostate epithelial cells, treatment with $1,25-\mathrm{D}_{3}$ caused clear changes in site-specific methylation of the $p 21$ promoter, in a cell line-specific manner (Doig et al., 2013).

An interesting interaction between vitamin $\mathrm{D}$ and DNA methylation is induction of the expression of GADD45 (growth arrest and DNA damage) protein by $1,25-\mathrm{D}_{3}$ in several tumor 
cells (Jiang et al., 2003; Zhang et al., 2006; Bremmer et al., 2012). GADD45A is one of the enzymes that promote epigenetic gene activation by repair mediated DNA demethylation in Xenopus laevis (Barreto et al., 2007).

In summary, alterations in DNA methylation lead to aberrant gene expression and disruptions of genomic integrity, which contribute to development and progression of diseases. Vitamin D can regulate these processes; the mechanisms behind need further investigations.

\section{INTERACTIONS OF VITAMIN D WITH CHROMATIN MODULATORS AND REMODELERS}

Nuclear receptors, such as the VDR contain DNA-binding domains that mediate binding to the DNA, presuming the DNA is available and is not wound tightly around nucleosomes. The chromatin context determines nuclear receptor binding and determines which epigenetic modifications will occur thereafter. Upon binding to their genomic response elements, nuclear hormone receptors will then recruit different regulatory cofactor complexes (Lee et al., 2001). The unliganded VDR is able to bind also genomic DNA, where it usually forms complexes with corepressor proteins that either exert HDAC activity, e.g., ALIEN (Polly et al., 2000), or are associated with HDACs, such as NCOR1 and SMRT. The corepressors dissociate upon binding of $1,25-\mathrm{D}_{3}$, and are replaced by coactivator complexes.

The chromatin environment dictates gene activity throughout the genome. Post-translational modifications of the N-terminal tails of histone proteins allow nucleosomes to shift, the chromatin to relax, and genes to become activated. Histone modifications change in response to environmental stimuli (Meyer et al., 2013). Histones are major protein components of chromatin that undergo post-translational modifications, including acetylation of lysines, methylation of lysines and arginines, and phosphorylation of serine and threonine residues (Esteller, 2008). In epigenetically silenced genes, hypermethylation of CGIs is often associated with loss of acetylation on histone 3 and 4 (H3 and H4), loss of methylation of lysine (K) 4 on $\mathrm{H} 3$ (H3K4), and gain of methylation of $\mathrm{K} 9$ and $\mathrm{K} 27$ on $\mathrm{H} 3$ (H3K9 and $\mathrm{H} 3 \mathrm{~K} 27$ ) (Esteller, 2008).
Histone acetylation generally correlates with transcriptional activation (Hebbes et al., 1988; Kouzarides, 2007) and is dependent on a dynamic interaction between histone acetyltransferases (HATs) and histone deacetylases (HDACs) (Marks et al., 2001). The balance between the actions of these enzymes is crucial in controlling gene expression, and governs several developmental processes and disease states (Haberland et al., 2009). Generally, HATs are defined as activators of transcription, whereas HDACs as transcription repressors (Parbin et al., 2014). In various cancer types, including prostate, gastric, and breast cancers, overexpression of HDAC1 is often associated with poor clinical outcome (Choi et al., 2001; Halkidou et al., 2004; Zhang et al., 2005). In colorectal cancer patients HDAC1, 2, and 3 are overexpressed, and high HDAC1 and 2 expression is linked with reduced patient survival (Zhu et al., 2004; Wilson et al., 2006). Overexpression of $\mathrm{HDAC} 1$ plays a crucial role in regulating proliferation by repressing the expression of the cyclin-dependent kinase inhibitor p21 (Lagger et al., 2003). Additionally, silencing of HDAC4 leads to re-expression of $\mathrm{p} 21$, which in turn induces cell growth arrest and tumor growth inhibition, both in vitro and in vivo in a human glioblastoma model (Mottet et al., 2009). In addition to classical HDACs, another group of enzymes, the sirtuins (silent information regulator 2 proteins) are involved in histone deacetylation (Schwer and Verdin, 2008). Sirtuins have been linked to metabolic disorders, cancer, aging, and also regulation of the circadian rhythm (Guarente, 2006; Longo and Kennedy, 2006; Jung-Hynes et al., 2010).

Many of the coactivators recruited by the VDR, including p160 steroid receptor coactivator proteins (SRC1, 2, and 3), p300, or CBP have lysine acetyltransferase activity (Figure 1). Indeed, treatment of THP-1 cells with $1,25-\mathrm{D}_{3}$ increased $\mathrm{H} 3 \mathrm{~K} 27 \mathrm{ac}$ at the promoter of several early VDR target genes (Seuter et al., 2013). In genetic hypercalciuric stone forming rats inhibition of bone morphogenetic protein 2 (BMP2) by $1,25-\mathrm{D}_{3}$, seems to involve $\mathrm{H} 3$ deacetylation and $\mathrm{H} 3 \mathrm{~K} 9$ di-methylation ( $\mathrm{Fu}$ et al., 2013).

In MDA-MB453 breast cancer cells $1,25-\mathrm{D}_{3}$ treatment regulates expression of p21 through a mechanism involving both histone acetylation and methylation, probably by dynamic
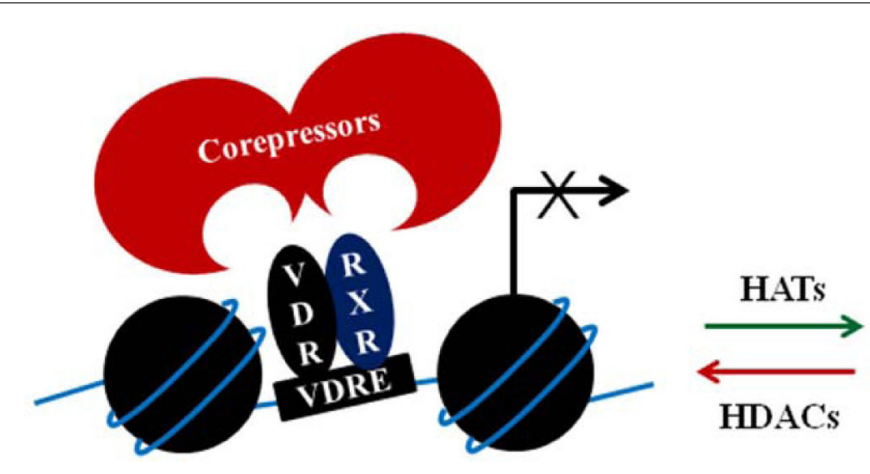

FIGURE 1 | Simplified illustration of a two-step coregulator model. The VDR/RXR complex in absence of the $1,25-D_{3}$ may bind corepressors that would lead/maintain gene repression, partly by attracting histone deacetylases (HDACs). Upon ligand binding to the
VDR/RXR complex, corepressors are replaced by coactivators, which include histone acetyltransferases (HATs). Acetylation of histones (indicated by the green stars) enables chromatin relaxation and gene transcription. 
chromatin looping from distal $1,25-\mathrm{D}_{3}$ responsive elements to the TSS of p21 (Saramäki et al., 2009).

Histone methylation can lead either to gene activation or repression, depending on the histone site that is methylated, the degree of methylation (e.g., mono-methylation, di-methylation, or tri-methylation), amino acid residues affected, and their position in the histone tail (Esteller, 2008). Methylation of histones depends on a dynamic process arising from the actions of methyltransferases (HMTs) and demethylases (HDMs) (Shi and Whetstine, 2007; Mosammaparast and Shi, 2010; Greer and Shi, 2012). So far, two protein families capable of demethylating lysines are known, the amine oxidases (Shi et al., 2004) and jumonji $\mathrm{C}$ (JmjC)-domain-containing proteins (Cloos et al., 2006; Tsukada et al., 2006). The first histone demethylase discovered was the lysine-specific demethylase 1 (LSD1/KDM1A), an amine oxidase, which demethylates H3K4me2/me1 (Table 1) (Shi et al., 2004). High expression of KDM1A in various cancers, including colorectal cancer, prostate cancer, and neuroblastomas is associated with increased cancer recurrence and poor clinical outcome (Kahl et al., 2006; Schulte et al., 2009; Ding et al., 2013). Additionally, it has been shown that LSD1 is essential for androgen and estrogen receptor-dependent gene activation via H3K9me2/me1 demethylation (Metzger et al., 2005; GarciaBassets et al., 2007; Perillo et al., 2008). There is a reciprocal regulatory effect between the activity of VDR and histone demethylases. In the colon cancer cell line SW480-ADH 1,25- $\mathrm{D}_{3}$ increased the expression of the lysine-specific demethylase 1 and 2 (Pereira et al., 2012).

$1,25-\mathrm{D}_{3}$ treatment affected also the expression of a series of different JmjC histone demethylases. The first identified member of the JmjC family was KDM2A/JHDM1A (Tsukada et al., 2006). Expression profiling data showed altered expression of KDM2A and KDM2B in several tumors, however, it seems that their proor antioncogenic functions are tissue-dependent (Frescas et al., 2007, 2008; Pfau et al., 2008). 1,25-D 3 inhibited the expression of several histone demethylases (e.g., KDM4A/4C/4D/5A/2B, JMJD5/6, PLA2G4B), and induced the expression of others, JARID2 and KDM5B (Pereira et al., 2012). Members of the KDM4 family catalyze tri-demethylation of $\mathrm{H} 3 \mathrm{~K} 9$ and/or H3K36 (Cloos et al., 2006; Fodor et al., 2006; Klose et al., 2006; Whetstine et al., 2006; Lin et al., 2008). H3K9me3 is a mark for heterochromatin and demethylation of $\mathrm{H} 3 \mathrm{~K} 9$ is suggested to be linked with chromosomal instability (Cloos et al., 2006). Inhibition of expression of KDM4 family members by $1,25-\mathrm{D}_{3}$ could thus contribute to genome stability. Members of KDM5 cluster catalyze demethylation of $\mathrm{H} 3 \mathrm{~K} 4 \mathrm{me} 3 / \mathrm{me} 2$, which is a mark for open chromatin (Christensen et al., 2007; Iwase et al., 2007; Klose et al., 2007; Tahiliani et al., 2007) and their upregulaton upon $1,25-\mathrm{D}_{3}$ treatment might lead to gene repression (Pereira et al., 2011). Overexpression of KDM5B has been reported in breast and prostate cancers (Lu et al., 1999; Xiang et al., 2007). Deletion of $k d m 5 b$ inhibits tumor growth in a syngeneic mouse mammary

Table 1 | A simplified list of the members of the two classes of histone demethylases (mentioned in the manuscript).

\begin{tabular}{|c|c|c|c|c|}
\hline $\begin{array}{l}\text { Class of } \\
\text { histone demethylases }\end{array}$ & $\begin{array}{l}\text { Histone } \\
\text { demethylase family }\end{array}$ & $\begin{array}{l}\text { Histone } \\
\text { demethylase }\end{array}$ & $\begin{array}{l}\text { Histone } \\
\text { substrate }\end{array}$ & $\begin{array}{l}\text { Gene } \\
\text { expression }\end{array}$ \\
\hline Amine oxidases & KDM1 & $\begin{array}{l}\text { KDM1A } \\
\text { KDM1B }\end{array}$ & $\begin{array}{l}\mathrm{H} 3 \mathrm{~K} 4 \mathrm{me} 2 / \mathrm{me} 1 \\
\mathrm{H} 3 \mathrm{~K} 9 \mathrm{me} 2 / \mathrm{me} 1 \\
\mathrm{H} 3 \mathrm{~K} 4 \mathrm{me} 2 / \mathrm{me} 1\end{array}$ & $\begin{array}{l}\text { Repression } \\
\text { Activation } \\
\text { Repression }\end{array}$ \\
\hline \multirow[t]{7}{*}{ Jumonji C-domain-containing proteins } & KDM2 & $\begin{array}{l}\text { KDM2A } \\
\text { KDM2B }\end{array}$ & $\begin{array}{l}\text { H3K36me2/me1 } \\
\text { H3K4me3 } \\
\text { H3K36me2/me1 }\end{array}$ & Repression \\
\hline & KDM3 & $\begin{array}{l}\text { KDM3A } \\
\text { KDM3B }\end{array}$ & $\begin{array}{l}\mathrm{H} 3 \mathrm{~K} 9 \mathrm{me} 2 / \mathrm{me} 1 \\
\mathrm{H} 3 \mathrm{~K} 9 \mathrm{me} 3 / \mathrm{me} 2 / \mathrm{me} 1\end{array}$ & Activation \\
\hline & KDM4 & $\begin{array}{l}\text { KDM4A } \\
\text { KDM4B } \\
\text { KDM4C }\end{array}$ & $\begin{array}{l}\text { H3K9me3/me2 } \\
\text { H3K36me3/me2 }\end{array}$ & $\begin{array}{l}\text { Activation } \\
\text { Repression }\end{array}$ \\
\hline & & KDM4D & $\mathrm{H} 3 \mathrm{~K} 9 \mathrm{me} / \mathrm{me} 2$ & Activation \\
\hline & KDM6 & $\begin{array}{l}\text { KDM6A } \\
\text { KDM6B }\end{array}$ & $\mathrm{H} 3 \mathrm{~K} 27 \mathrm{me} 3 / \mathrm{me} 2$ & Activation \\
\hline & PHF & JHDM1D & $\begin{array}{l}\text { H3K9me2/me1 } \\
\text { H3K27me2/me1 }\end{array}$ & Activation \\
\hline & & PHF8 & $\mathrm{H} 3 \mathrm{~K} 9 \mathrm{me} 2 / \mathrm{me} 1$ & \\
\hline
\end{tabular}

Reviewed in Pedersen and Helin (2010), Greer and Shi (2012). The main histone demethylase families and submembers are indicated. Degree of methylation and site of lysine residue are given. References for individual enzymes can be found throughout the text. $H$, Histone; $K$, lysine; me1, mono-methylation; me2, di-methylation; me3, tri-methylation; KDM1A, lysine-specific demethylase 1A; JHDM1D, JmjC-domain-containing histone demethylation protein 1D; PHF, plant homeodomain finger protein. 
tumor (Yamane et al., 2007), suggestive of its potential role in tumor development. 1,25- $\mathrm{D}_{3}$ induced the expression of the histone demethylase KDM6B as well, which is the only other known enzyme, besides KDM6A that is able to demethylate $\mathrm{H} 3 \mathrm{~K} 27 \mathrm{me} 3$, a histone mark that correlates with gene repression. Furthermore, the authors showed positive correlation between KDM6B and VDR in 96 colon tumor patients, and inverse correlation of KDM6B with SNAIL1, which is involved in epithelial to mesenchymal transition, indicating that probably the antiproliferative role of $1,25-\mathrm{D}_{3}$ via $\mathrm{KDM} 6 \mathrm{~B}$ upregulation might take place in vivo (Pereira et al., 2011). Interestingly, treatment of SW480-ADH cells with $1,25-\mathrm{D}_{3}$ had no effect on global H3K27me3 levels, in spite of KDM6B upregulation (Pereira et al., 2011, 2012). The effect of $1,25-\mathrm{D}_{3}$ on the expression of histone demethylases may well be indirect and could be mediated by microRNAs (Padi et al., 2013). KDM2A is one of the direct targets of microRNA-627. $1,25-\mathrm{D}_{3}$-dependent upregulation of the microRNA-627 expression both in vitro, in the HT-29 colorectal cancer cells and in vivo, in tumor xenografts, led to lower KDM2A levels (Padi et al., 2013).

In different pathologies, the expression pattern of the nuclear receptor cofactors is altered, compromising the effect of $1,25-\mathrm{D}_{3}$ (Doig et al., 2013; Singh et al., 2013). The initial interactions between VDR and coactivators are the seed for the assembly of intricate multiprotein complexes that remodel the chromatin structure, recruit the core transcriptional machinery, and induce expression of 1,25- $\mathrm{D}_{3}$ target genes (Figure 1). Often, differences in responsiveness to $1,25-\mathrm{D}_{3}$ depend on the expression pattern of the coregulators of VDR. In prostate cancer cells, the temporal distribution of the nuclear corepressor NCOR1 at VDR target genes is different in $1,25-\mathrm{D}_{3}$ responsive cells compared with unresponsive cells (Doig et al., 2013; Singh et al., 2013).

The liganded VDR is able both to transactivate and transrepress target genes. The mechanisms of action are probably different between transactivation and transrepression, and also highly dependent on the motifs of the vitamin D response elements. A highly complex mechanism regulates the liganddependent repression of CYP27B1 (Kim et al., 2007a). CYP27B1 repression requires two epigenetic modifications: deacetylation of histones and methylation of the CYP27B1 gene promoter and exon regions. This is dependent on the presence of the VDR interacting repressor (VDIR) and the chromatin remodeler Williams Syndrome transcription factor. In the absence of $1,25-\mathrm{D}_{3}$, VDIR is bound directly to the E-box motifs in the negative VDRE and recruits histone acetyltransferases to induce CYP27B1 gene transcription. In the presence of $1,25-\mathrm{D}_{3}, \mathrm{VDIR}$ acts as a scaffold for the $1,25-\mathrm{D}_{3}-\mathrm{VDR}$ complex to repress transcription of $C Y P 27 B 1$ through recruitment of HDAC2, DNMT1, and DNMT3B (Kim et al., 2007a). It seems that VDIR and HDAC2 are involved also in the $1,25-\mathrm{D}_{3}$-dependent transrepression of the human parathyroid hormone gene (Kim et al., 2007b). It is not clear, whether this mechanism of transrepression by liganded VDR also applies to other genes. In mesenchymal stem cells $1,25-\mathrm{D}_{3}$ represses gene expression by binding to promoters with enhanced H3K9Ac and H3K9me2 (Tan et al., 2009). Whether H3K9 acetylation/methylation enabled VDR binding or VDR binding caused $\mathrm{H} 3 \mathrm{~K} 9$ acetylation, is not clear.
Proper orchestration of histone modifications in crosstalk with other chromatin regulators is crucial in maintaining the epigenetic landscape and governing gene expression. Any disturbances in these constellations may lead to aberrant gene expression. Whether $1,25-\mathrm{D}_{3}$ affects regulation of other chromatin modulators as well, is not yet known.

\section{REGULATION OF THE VITAMIN D SYSTEM}

The vitamin $\mathrm{D}$ system has pleiotropic functions and regulates approximately $3 \%$ of the human genome (Bouillon et al., 2008). To maintain balance, a strict regulation of the vitamin D system genes is of utmost importance. The main role of liganded VDR in tissues not involved in calcium homeostasis is to control expression of genes that regulate cell proliferation, differentiation, and apoptosis. One major limitation in the therapeutic exploitation of these effects is the resistance of cancer cells to $1,25-\mathrm{D}_{3}$. Epigenetic corruption of VDR signaling is suggested to be one of the mechanisms that leads to reduced responsiveness to $1,25-\mathrm{D}_{3}$ actions. This can be caused by promoter methylation of key vitamin D system genes or by skewed accumulation of VDR-associated corepressors, preferentially at promoters of anti-proliferative target genes (Abedin et al., 2006).

Expression of the vitamin D degrading and metabolizing enzymes is regulated through binding of $1,25-\mathrm{D}_{3}$-liganded VDR to vitamin $\mathrm{D}$ responsive elements (VDREs). However, the major regulators of $1,25-\mathrm{D}_{3}$ levels and signaling CYP2R1, CYP24A1, CYP27B1, and VDR, "the vitamin D tool" genes, are prone to epigenetic regulation. $\mathrm{CpG}$ islands span the promoters of $C Y P 2 R 1$, $C Y P 24 A 1$, and $V D R$, while a CpG island is located within the CYP27B1 gene locus (Figure 2). Therefore, DNA methylation and histone modifications in these regions can change the chromatin state from an open to closed conformation and lead to transcriptional repression of these genes. Expression of vitamin D tool genes becomes deregulated in various types of cancer, and these changes may be partially attributed to epigenetic alterations (reviewed in Hobaus et al., 2013). As early as 1984, Yoneda et al. (1984) have shown that the histone acetyltransferase inhibitor butyrate augments $1,25-\mathrm{D}_{3}$ actions. Several studies confirmed these findings (e.g., Rashid et al., 2001) and have suggested that the action of butyrate could be through upregulation of VDR or CYP27B1 expression (Gaschott and Stein, 2003). Whether this effect is mediated by direct acetylation of the VDR or CYP27B1 promoters, has not been determined.

In this chapter we discuss evidence for epigenetic regulation through DNA methylation of these genes in health and disease.

\section{EPIGENETIC REGULATION OF THE VITAMIN D RECEPTOR}

The VDR is a nuclear receptor mediating $1,25-\mathrm{D}_{3}$ signaling. It is expressed by at least 38 cell types in the human body (Norman and Bouillon, 2010). In the absence of its ligand $1,25-\mathrm{D}_{3}, \mathrm{VDR}$ is mainly found in the cytoplasm (Nagpal et al., 2005). Upon ligand binding, VDR heterodimerizes with the retinoid $\mathrm{X}$ receptor (RXR) and translocates to the nucleus, where it binds to vitamin D responsive elements (VDREs) to regulate transcription of $1,25-\mathrm{D}_{3}$ target genes. This is achieved through recruitment of coactivators or corepressors to the VDR-RXR complex bound to DNA (Nagpal et al., 2005; Pike et al., 2012; Haussler et al., 2013; 


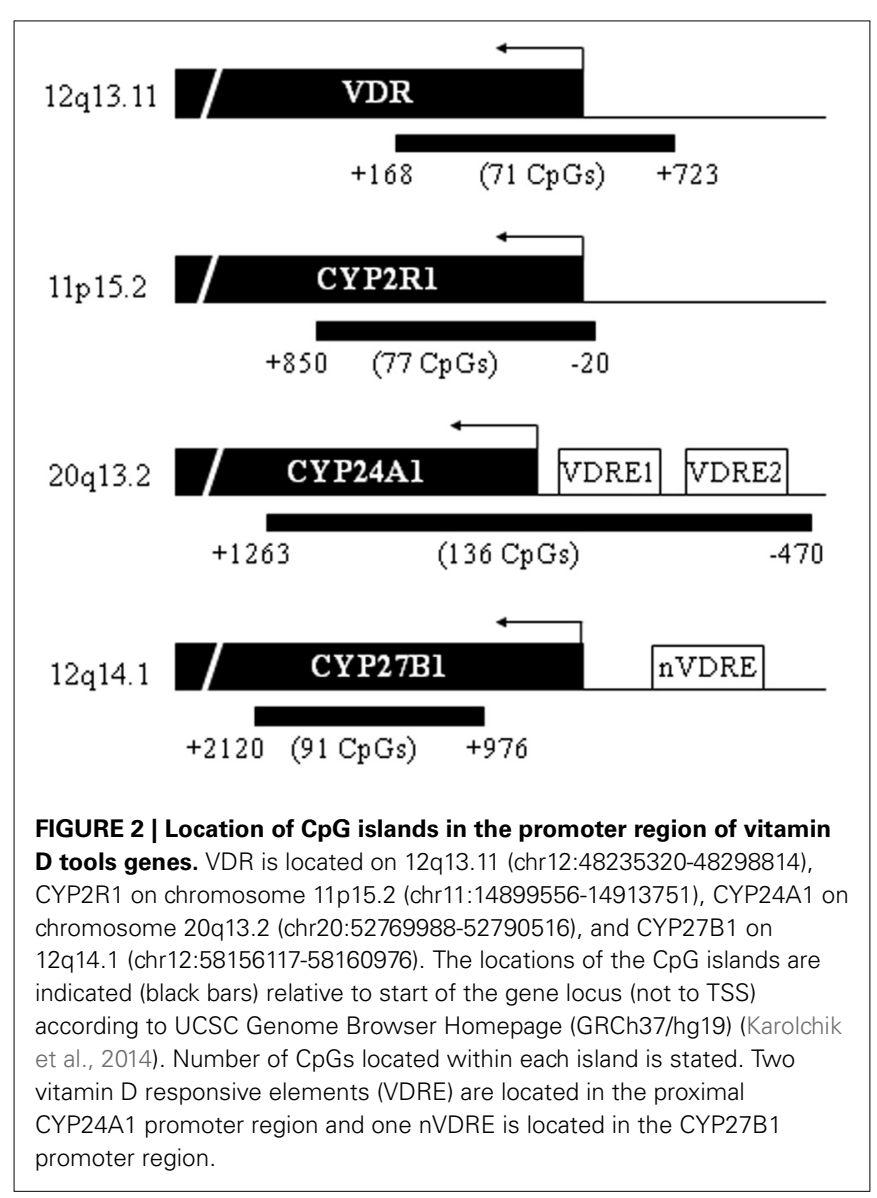

Pike and Meyer, 2013). As VDR is rarely mutated during carcinogenesis (Miller et al., 1997), the disturbance of the vitamin $\mathrm{D}$ signaling and apparent $1,25-\mathrm{D}_{3}$ insensitivity in cancer (Marik et al., 2010) must be attributed to other alterations, which may include epigenetic changes, such as promoter methylation.

The VDR gene is located on the long arm of chromosome 12 (12q13.11) and contains 4 potential promoter regions. Exons 1a, $1 c$, and $1 \mathrm{~d}$ of the $V D R$ are well conserved, while $1 \mathrm{~b}, 1 \mathrm{e}$, and $1 \mathrm{f}$ show low homology (Halsall et al., 2007). Exon 1a appears to contain a strong promoter, including several transcription factor binding sites (AP-2 and SP1). Transcription was reported to originate also in exons $1 \mathrm{~d}, 1 \mathrm{e}$, and $1 \mathrm{f}$, while translation starts in exon 2 (Halsall et al., 2007). Marik and colleagues performed an in silico analysis of the VDR gene sequence and reported three CpG islands located in exon la spanning from $-790 \mathrm{bp}$ to $380 \mathrm{bp}$ relative to the TSS in exon 1a (Marik et al., 2010). According to the UCSC Genome browser, however, only one large CpG island spanning $892 \mathrm{bp}$ in length is found in the VDR promoter region (Gardiner-Garden and Frommer, 1987; Karolchik et al., 2014). This discrepancy is likely due to the different search parameters used for CpG island identification.

Epigenetic silencing of VDR was suggested to cause the slow normalization of VDR levels in the parathyroid glands of uremic rats after kidney transplantation (Lewin et al., 2002; HofmanBang et al., 2012). However, sequencing of the VDR promoter [ -250 to $300 \mathrm{bp}$ relative to exon 1 (43 CpGs)] in normal and uremic rats showed no difference between methylation patterns (Hofman-Bang et al., 2012). Further, the authors reported that methylation levels coincided with the negative control, thus showing that promoter methylation does not play a role in regulating VDR expression in the parathyroid glands.

In contrast, promoter methylation was reported to cause repression of VDR gene expression in HIV infected T cells. In normal $\mathrm{T}$ cells, activation or priming causes an upregulation of VDR expression (Von Essen et al., 2010). In comparison, infection of previously activated $\mathrm{T}$ cells with human immunodeficiency virus (HIV) led to upregulation of DNMT3B, increased promoter methylation of VDR (45-70\%), and decreased VDR gene expression (Chandel et al., 2013). This downregulation of VDR could be reversed upon treatment with 5-azacytidine (AZA) suggesting that the decreased expression of VDR by HIV is, at least partially, caused by DNA methylation (Chandel et al., 2013). There is evidence for an inverse correlation between the vitamin D status and infections, however, many trials failed to show a protective effect of vitamin D (reviewed in Yamshchikov et al., 2009). Thus, reduced sensitivity to vitamin D metabolites due to, e.g., downregulation of VDR may account for inconclusive trials. This is supported by a study investigating methylation of the $3^{\prime}$ end of VDR in two South African groups revealing differences with respect to ethnicity and tuberculosis status of the patients (Andraos et al., 2011).

In breast tumors, methylation of exon 1a of the $V D R$ gene was significantly higher (65\% of CpGs methylated) compared with normal breast tissue (15\% of CpGs methylated) (Marik et al., 2010). In vitro, in breast cancer cell lines, three hypermethylated regions in exon la became demethylated after treatment with the DNMT1 inhibitor 5-aza-2'-deoxycytidine (DAC) and VDR mRNA expression increased. These regions were in proximity to the SP1 binding sites (approximately $790 \mathrm{bp}$ from TSS), NFKB binding sites (approximately -480 from TSS), and the exon 1a TSS. Treatment with $1,25-\mathrm{D}_{3}$ had no effect on methylation of these regions (Marik et al., 2010). In other types of cancer, e.g., the choriocarcinoma-derived trophoblast cell lines JEG-3 and JAR, the VDR promoter was densely methylated (Novakovic et al., 2009). In contrast, no methylation of the VDR promoter region was observed in colon cancer cell lines, and treatment with DAC did not increase gene expression (Habano et al., 2011; Höbaus et al., 2013a). In parathyroid tumors the expression of VDR is decreased (Gogusev et al., 1997; Carling et al., 2000), however, no differences in DNA methylation of VDR were observed between parathyroid tumors and healthy controls (Sulaiman et al., 2013). Similar results were seen in parathyroid adenoma samples, which showed decreased expression of VDR, but showed no promoter methylation (Varshney et al., 2013).

Additionally, it has been suggested that expression of $5^{\prime}$ truncated variants of VDR is linked to methylation of the VDR promoter. These variants are predominantly found in breast cancer compared with the full length variants expressed in normal breast tissue. Treatment with DAC restored expression of the active transcript variant of VDR in breast cancer cell lines, indicating promoter methylation as cause of truncated protein expression (Marik et al., 2010). The significance of these potentially untranslated truncated variants remains to be investigated, however, as 
they are not found in normal breast tissue aberrant expression of truncated isoforms may further disrupt vitamin D signaling in tumor tissue.

A recent study suggested that in colorectal cancer metastases, VDR becomes the target of the polycomb group protein enhancer of zeste homolog 2 (EZH2) that mediates VDR downregulation by H3K27 trimethylation in the VDR promoter (Lin et al., 2013). The histone deacetylase HDAC3, one of the most frequently upregulated genes in cancer, seems to inhibit VDR expression. In two colorectal cancer cell lines, HCT116 and SW480 knock down of HDAC3 increased VDR expression and restored sensitivity of these cells to 1,25-D (Godman et al., 2008).

Taken together, there is evidence that in various diseases the decreased tissue sensitivity to $1,25-\mathrm{D}_{3}$ could have been caused by the epigenetic silencing of the VDR.

\section{EPIGENETIC REGULATION OF THE CYP2R1}

CYP2R1 is a microsomal P450 enzyme, which hydroxylates both vitamin $\mathrm{D}_{2}$ and $\mathrm{D}_{3}$ at position C-25 to form the circulating storage form of vitamin $\mathrm{D}_{2} 25-\mathrm{D}_{3}$. The promoter region of CYP2R1 is located within a $\mathrm{CpG}$ island, which can be subjected to epigenetic regulation. So far, only two studies investigated the promoter methylation status of this gene. Genome wide association studies found increased CYP2R1 promoter methylation in leukocyte DNA from individuals with severe vitamin D deficiency compared with control group (Zhu et al., 2013). Further, methylation levels of CYP2R1 promoter decreased within 12 months of vitamin D supplementation in DNA extracted from serum of nonHispanic white American post-menopausal women aged $\geq 55$ years (Zhu et al., 2013), indicating an effect of vitamin D supplementation on $C Y P 2 R 1$ promoter methylation. These data indicate that under low vitamin $D$ serum levels, the promoter of the major 25-hydroxylase CYP2R1 may become methylated, and that event appears to be reversible upon exposure to increased vitamin D.

\section{EPIGENETIC REGULATION OF THE CYP27B1}

CYP27B1 is an inner mitochondrial membrane P450 enzyme that converts 25-D3 to its active form 1,25-D3. It is mainly expressed in the proximal tubule of the kidneys, but it is also expressed in many vitamin $\mathrm{D}$ target tissues, albeit at lower levels (Hendrix et al., 2004). The CYP27B1 gene harbors a CpG island. However, recent sequence updates (Ensembl 74, November 2013) shift the $\mathrm{CpG}$ island from the CYP27B1 promoter region into the gene coding sequence (Flicek et al., 2014). This explains the differences between the location of the CpG island depicted in Figure 2 and the location of the $\mathrm{CpG}$ island described in literature. For simplicity, statements on nVDRES and CpG island location below refer to reports in the published articles and not to Figure 2 .

The promoter region of CYP27B1 contains a negative VDRE (nVDRE) located at around $500 \mathrm{bp}$, consisting of two E-box like motifs (Murayama et al., 2004). This region is responsible for 1,25- $\mathrm{D}_{3}$-dependent transrepression, which seems to be achieved through recruitment of both HDACs and DNMTs by VDR/RXR to the promoter region of CYP27B1 (Takeyama and Kato, 2011). For further details see subsection Interactions of Vitamin D with Chromatin Modulators and Remodelers.
In cancer, expression of CYP27B1 is often downregulated. This may be explained by increased methylation of the $\mathrm{CpG}$ island located within $C Y P 27 B 1$. In the breast cancer cells MDA-MB231, CYP27B1 hypermethylation led to gene silencing, which could be reversed by treatment with deoxyC (Shi et al., 2002). In prostate cancer cell lines, combination of the DNMT1 inhibitor DAC and the HDAC inhibitor TSA resulted in increased activity of CYP27B1 (Khorchide et al., 2005). In the choriocarcinoma cell lines BeWo and JAR the promoter of CYP27B1 was densely methylated (Novakovic et al., 2009). The CYP27B1 promoter was hypermethylated (61\%) in Non-Hodgkin's lymphoma, but not in benign follicular hyperplasia. Two out of four non-Hodgkin's lymphoma cell lines showed strong methylation of the CYP27B1 promoter. Interestingly, all four responded to DAC-TSA treatments with upregulation of gene expression independent of the methylation status of their CYP27B1 promoter, which may be explained by other regions prone to methylation not investigated in this study or by differences in silencing mechanisms (Shi et al., 2007). Further, the methylation level of CYP27B1 was increased in primary lymphoma and leukemia cells also compared with normal peripheral blood lymphocytes (Lagger et al., 2003; Wjst et al., 2010).

Methylation of CYP27B1 in diseases might cause reduced local activation of $25-\mathrm{D}_{3}$ to $1,25-\mathrm{D}_{3}$, thus reducing local $1,25-\mathrm{D}_{3}$ levels and restricting its functions.

\section{EPIGENETIC REGULATION OF CYP24A1}

The 1,25-dihydroxyvitamin $\mathrm{D}_{3}$ 24-hydroxylase is an inner mitochondrial membrane $\mathrm{P} 450$ enzyme, which catalyzes both $25-\mathrm{D}_{3}$ and 1,25-D 3 (Kawashima et al., 1981; Pedersen et al., 1983; Sakaki et al., 2000). Its primary site of expression are the kidneys, where it plays a crucial role in regulating systemic vitamin D metabolite levels, however, expression is found in many other vitamin D target tissues.

The promoter of CYP24A1 is spanned by a CpG island making it prone to regulation by DNA methylation. Several responsive elements are located within this area, including two VDREs, a vitamin stimulating element (VSE), and SP1 binding sites (see Figure 2).

In healthy kidney, skeletal muscle, whole blood, brain, skin fibroblasts, and sperm the CYP24A1 promoter is not methylated (Novakovic et al., 2009), although the expression levels are highly variable. In peripheral blood lymphocytes methylation of CYP24A1 was low (5\%) (Wjst et al., 2010). Interestingly, in full term human placenta $56.5 \%$ of the CYP24A1 promoter is methylated. CYP24A1 methylation was also observed in the placenta of the marmoset and mouse, however, at a lower level.

In the choriocarcinoma cell lines JEG-3, BeWo, and JAR the promoter of CYP24A1 was densely methylated and the methylation level correlated inversely with the low gene expression (Novakovic et al., 2009). Treatment of osteoblastic ROS cells with $1,25-\mathrm{D}_{3}$ did not induce CYP24A1 expression. Considering the strong methylation of the CYP24A1 promoter region, epigenetic silencing of CYP24A1 may account for the unresponsiveness of this gene to $1,25-\mathrm{D}_{3}$ (Ohyama et al., 2002). In the human prostate cancer cell line PC3, methylation of the CYP24A1 
promoter reduced reporter gene expression in a methylationdependent manner (Luo et al., 2010). In prostate cancer cells, the methylation status of CYP24A1 promoter inversely correlated with gene expression. Demethylating agents restored CYP24A1 expression only in cell lines where the CYP24A1 promoter was methylated prior to treatment (Luo et al., 2010). Only DNA demethylation by DAC treatment permitted recruitment of VDR to the CYP24A1 promoter (Luo et al., 2010). In patients, development from benign toward malignant prostate lesions was paralleled by increasing methylation levels of the CYP24A1 promoter (Luo et al., 2010). Prostate tumor derived endothelial cells (TDEC) expressed less CYP24A1 compared with endothelial cells derived from normal cells or matrigel plugs, which may be attributed to increased CYP24A1 promoter methylation in TDECs (Johnson et al., 2010). We have shown recently that in colon cancer cell lines DAC induced CYP24A1 expression in a cell line-specific manner, independent of the methylation level of the promoter. In these cells induction of CYP24A1 expression by DAC seems to be independent of CYP24A1 promoter methylation (Höbaus et al., 2013a). Moreover, the methylation level of the CYP24A1 promoter was comparably low both in colon adenocarcinomas and the adjacent mucosa, although the expression of CYP24A1 was significantly higher in the tumors (Höbaus et al., 2013b).

Taken together, the regulation of CYP24A1 by DNA methylation appears to be tissue-dependent, both in health and disease.

\section{CONCLUSIONS}

There is a strong reciprocity between the vitamin D system and epigenetic mechanisms. The vitamin D system is, on the one hand regulated by epigenetic mechanisms and, on the other hand, is involved in regulating epigenetic events. Critical vitamin D tool genes can be silenced by DNA methylation. The VDR protein interacts, directly or indirectly, with chromatin modifiers and remodelers. Liganded VDR regulates expression of several of these chromatin modifiers and remodelers, and it might even regulate DNA methylation.

Epigenetic regulation of gene expression is a fine-tuned mechanism and its deregulation can lead to pathological conditions. The impact of vitamin $\mathrm{D}$ in the maintenance of the normal epigenetic landscape underlines the central role of this hormone in physiology.

\section{PERSPECTIVES}

One of the most fundamental questions in the control of gene expression is the way how epigenetic marks are established, erased, and recognized. Regulating epigenetic events could be a further mechanism by which $1,25-\mathrm{D}_{3}$ may prevent or delay tumorigenesis and onset of chronic diseases. Therefore, we need to understand better the impact of vitamin D on the epigenome, and plan thorough and comprehensive studies to examine this interplay.

\section{ACKNOWLEDGMENTS}

We thank the Austrian Research Fund (FWF) Grant P22200-B11 and the European Union, FP7-PEOPLE-2010 Grant 264663 for support.

\section{REFERENCES}

Abedin, S. A., Banwell, C. M., Colston, K. W., Carlberg, C., and Campbell, M. J. (2006). Epigenetic corruption of VDR signalling in malignancy. Anticancer Res. 26, 2557-2566.

Aguilera, O., Pena, C., Garcia, J. M., Larriba, M. J., Ordonez-Moran, P., Navarro, D., et al. (2007). The Wnt antagonist DICKKOPF-1 gene is induced by lalpha,25dihydroxyvitamin D3 associated to the differentiation of human colon cancer cells. Carcinogenesis 28, 1877-1884. doi: 10.1093/carcin/bgm094

Andraos, C., Koorsen, G., Knight, J. C., and Bornman, L. (2011). Vitamin D receptor gene methylation is associated with ethnicity, tuberculosis, and TaqI polymorphism. Hum. Immunol. 72, 262-268. doi: 10.1016/j.humimm.2010. 12.010

Arasaradnam, R. P., Commane, D. M., Bradburn, D., and Mathers, J. C. (2008). A review of dietary factors and its influence on DNA methylation in colorectal carcinogenesis. Epigenetics 3, 193-198. doi: 10.4161/epi.3.4.6508

Ballestar, E., and Esteller, M. (2005). Methyl-CpG-binding proteins in cancer: blaming the DNA methylation messenger. Biochem. Cell Biol. 83, 374-384. doi: 10.1139/o05-035

Barreto, G., Schafer, A., Marhold, J., Stach, D., Swaminathan, S. K., Handa, V., et al. (2007). Gadd45a promotes epigenetic gene activation by repair-mediated DNA demethylation. Nature 445, 671-675. doi: 10.1038/nature05515

Baylin, S. B., and Jones, P. A. (2011). A decade of exploring the cancer epigenome biological and translational implications. Nat. Rev. Cancer 11, 726-734. doi: $10.1038 / \mathrm{nrc} 3130$

Bestor, T. H. (2005). Transposons reanimated in mice. Cell 122, 322-325. doi: 10.1016/j.cell.2005.07.024

Bird, A. (2002). DNA methylation patterns and epigenetic memory. Genes Dev. 16, 6-21. doi: 10.1101/gad.947102

Bird, A. P. (1980). DNA methylation and the frequency of CpG in animal DNA. Nucleic Acids Res. 8, 1499-1504. doi: 10.1093/nar/8.7.1499

Bjornsson, H. T., Brown, L. J., Fallin, M. D., Rongione, M. A., Bibikova, M., Wickham, E., et al. (2007). Epigenetic specificity of loss of imprinting of the IGF2 gene in Wilms tumors. J. Natl. Cancer Inst. 99, 1270-1273. doi: 10.1093/jnci/djm069

Bouillon, R., Carmeliet, G., Verlinden, L., Van Etten, E., Verstuyf, A., Luderer, H. F., et al. (2008). Vitamin D and human health: lessons from vitamin D receptor null mice. Endocr. Rev. 29, 726-776. doi: 10.1210/er.2008-0004

Bremmer, F., Thelen, P., Pottek, T., Behnes, C. L., Radzun, H. J., and Schweyer, S. (2012). Expression and function of the vitamin D receptor in malignant germ cell tumour of the testis. Anticancer Res. 32, 341-349.

Brock, M. V., Hooker, C. M., Ota-Machida, E., Han, Y., Guo, M., Ames, S., et al. (2008). DNA methylation markers and early recurrence in stage I lung cancer. N. Engl. J. Med. 358, 1118-1128. doi: 10.1056/NEJMoa0706550

Carling, T., Rastad, J., Szabó, E., Westin, G., and Akerström, G. (2000). Reduced parathyroid vitamin $\mathrm{D}$ receptor messenger ribonucleic acid levels in primary and secondary hyperparathyroidism. J. Clin. Endocrinol. Metab. 85, 2000-2003. doi: 10.1210/jc.85.5.2000

Chandel, N., Husain, M., Goel, H., Salhan, D., Lan, X., Malhotra, A., et al. (2013). VDR hypermethylation and HIV-induced T cell loss. J. Leukoc. Biol. 93, 623-631. doi: 10.1189/jlb.0812383

Choi, J. H., Kwon, H. J., Yoon, B. I., Kim, J. H., Han, S. U., Joo, H. J., et al. (2001). Expression profile of histone deacetylase 1 in gastric cancer tissues. Jpn. J. Cancer Res. 92, 1300-1304. doi: 10.1111/j.1349-7006.2001.tb02153.x

Christensen, J., Agger, K., Cloos, P. A., Pasini, D., Rose, S., Sennels, L., et al. (2007). RBP2 belongs to a family of demethylases, specific for tri-and dimethylated lysine 4 on histone 3. Cell 128, 1063-1076. doi: 10.1016/j.cell.2007.02.003

Cloos, P. A., Christensen, J., Agger, K., Maiolica, A., Rappsilber, J., Antal, T., et al. (2006). The putative oncogene GASC1 demethylates tri- and dimethylated lysine 9 on histone H3. Nature 442, 307-311. doi: 10.1038/nature04837

Cui, H., Cruz-Correa, M., Giardiello, F. M., Hutcheon, D. F., Kafonek, D. R., Brandenburg, S., et al. (2003). Loss of IGF2 imprinting: a potential marker of colorectal cancer risk. Science 299, 1753-1755. doi: 10.1126/science.1080902

Ding, J., Zhang, Z. M., Xia, Y., Liao, G. Q., Pan, Y., Liu, S., et al. (2013). LSD1mediated epigenetic modification contributes to proliferation and metastasis of colon cancer. Br. J. Cancer 109, 994-1003. doi: 10.1038/bjc.2013.364

Doig, C. L., Singh, P. K., Dhiman, V. K., Thorne, J. L., Battaglia, S., Sobolewski, M., et al. (2013). Recruitment of NCOR1 to VDR target genes is enhanced in prostate cancer cells and associates with altered DNA methylation patterns. Carcinogenesis 34, 248-256. doi: 10.1093/carcin/bgs331 
Eden, A., Gaudet, F., Waghmare, A., and Jaenisch, R. (2003). Chromosomal instability and tumors promoted by DNA hypomethylation. Science 300, 455. doi: $10.1126 /$ science. 1083557

Esteller, M. (2007a). Epigenetic gene silencing in cancer: the DNA hypermethylome. Hum. Mol. Genet. 16, Spec No 1, R50-R59. doi: 10.1093/hmg/ddm018

Esteller, M. (2007b). Epigenetics provides a new generation of oncogenes and tumour-suppressor genes. Br. J. Cancer 96(Suppl.), R26-R30. doi: 10.1038/sj. bjc. 6602918

Esteller, M. (2008). Epigenetics in cancer. N. Engl. J. Med. 358, 1148-1159. doi: 10.1056/NEJMra072067

Esteller, M., Catasus, L., Matias-Guiu, X., Mutter, G. L., Prat, J., Baylin, S. B., et al. (1999). hMLH1 promoter hypermethylation is an early event in human endometrial tumorigenesis. Am. J. Pathol. 155, 1767-1772. doi: 10.1016/S00029440(10)65492-2

Feinberg, A. P., Cui, H., and Ohlsson, R. (2002). DNA methylation and genomic imprinting: insights from cancer into epigenetic mechanisms. Semin. Cancer Biol. 12, 389-398. doi: 10.1016/S1044-579X(02)00059-7

Ficz, G., Branco, M. R., Seisenberger, S., Santos, F., Krueger, F., Hore, T. A., et al. (2011). Dynamic regulation of 5-hydroxymethylcytosine in mouse ES cells and during differentiation. Nature 473, 398-402. doi: 10.1038/nature10008

Flicek, P., Amode, M. R., Barrell, D., Beal, K., Billis, K., Brent, S., et al. (2014). Ensembl 2014. Nucleic Acids Res. 42, D749-D755. doi: 10.1093/nar/gkt1196

Fodor, B. D., Kubicek, S., Yonezawa, M., O’Sullivan, R. J., Sengupta, R., PerezBurgos, L., et al. (2006). Jmjd2b antagonizes H3K9 trimethylation at pericentric heterochromatin in mammalian cells. Genes Dev. 20, 1557-1562. doi: 10.1101/gad.388206

Frescas, D., Guardavaccaro, D., Bassermann, F., Koyama-Nasu, R., and Pagano, M. (2007). JHDM1B/FBXL10 is a nucleolar protein that represses transcription of ribosomal RNA genes. Nature 450, 309-313. doi: 10.1038/nature06255

Frescas, D., Guardavaccaro, D., Kuchay, S. M., Kato, H., Poleshko, A., Basrur, V., et al. (2008). KDM2A represses transcription of centromeric satellite repeats and maintains the heterochromatic state. Cell Cycle 7, 3539-3547. doi: $10.4161 /$ cc.7.22.7062

Fu, B., Wang, H., Wang, J., Barouhas, I., Liu, W., Shuboy, A., et al. (2013). Epigenetic regulation of BMP2 by 1,25-dihydroxyvitamin D3 through DNA methylation and histone modification. PLoS ONE 8:e61423. doi: 10.1371/journal.pone.0061423

Garcia-Bassets, I., Kwon, Y. S., Telese, F., Prefontaine, G. G., Hutt, K. R., Cheng, C. S., et al. (2007). Histone methylation-dependent mechanisms impose ligand dependency for gene activation by nuclear receptors. Cell 128, 505-518. doi: 10.1016/j.cell.2006.12.038

Gardiner-Garden, M., and Frommer, M. (1987). CpG islands in vertebrate genomes. J. Mol. Biol. 196, 261-282. doi: 10.1016/0022-2836(87)90689-9

Gaschott, T., and Stein, J. (2003). Short-chain fatty acids and colon cancer cells: the vitamin D receptor-butyrate connection. Recent Results Cancer Res. 164, 247-257. doi: 10.1007/978-3-642-55580-0_18

Godman, C. A., Joshi, R., Tierney, B. R., Greenspan, E., Rasmussen, T. P., Wang, H. W., et al. (2008). HDAC3 impacts multiple oncogenic pathways in colon cancer cells with effects on Wnt and vitamin D signaling. Cancer Biol. Ther. 7, 1570-1580. doi: 10.4161/cbt.7.10.6561

Gogusev, J., Duchambon, P., Hory, B., Giovannini, M., Goureau, Y., Sarfati, E., et al. (1997). Depressed expression of calcium receptor in parathyroid gland tissue of patients with hyperparathyroidism. Kidney Int. 51, 328-336. doi: 10.1038/ki.1997.41

Greer, E. L., and Shi, Y. (2012). Histone methylation: a dynamic mark in health, disease and inheritance. Nat. Rev. Genet. 13, 343-357. doi: 10.1038/nrg3173

Greger, V., Passarge, E., Höpping, W., Messmer, E., and Horsthemke, B. (1989). Epigenetic changes may contribute to the formation and spontaneous regression of retinoblastoma. Hum. Genet. 83, 155-158. doi: 10.1007/BF00 286709

Gruenbaum, Y., Stein, R., Cedar, H., and Razin, A. (1981). Methylation of CpG sequences in eukaryotic DNA. FEBS Lett. 124, 67-71. doi: 10.1016/00145793(81)80055-5

Guarente, L. (2006). Sirtuins as potential targets for metabolic syndrome. Nature 444, 868-874. doi: 10.1038/nature05486

Habano, W., Gamo, T., Terashima, J., Sugai, T., Otsuka, K., Wakabayashi, G., et al. (2011). Involvement of promoter methylation in the regulation of Pregnane $\mathrm{X}$ receptor in colon cancer cells. BMC Cancer 11:81. doi: 10.1186/14712407-11-81
Haberland, M., Montgomery, R. L., and Olson, E. N. (2009). The many roles of histone deacetylases in development and physiology: implications for disease and therapy. Nat. Rev. Genet. 10, 32-42. doi: 10.1038/nrg2485

Hackett, J. A., Sengupta, R., Zylicz, J. J., Murakami, K., Lee, C., Down, T. A., et al. (2013). Germline DNA demethylation dynamics and imprint erasure through 5-hydroxymethylcytosine. Science 339, 448-452. doi: 10.1126/science. 1229277

Halkidou, K., Gaughan, L., Cook, S., Leung, H. Y., Neal, D. E., and Robson, C. N. (2004). Upregulation and nuclear recruitment of HDAC1 in hormone refractory prostate cancer. Prostate 59, 177-189. doi: 10.1002/pros.20022

Halsall, J. A., Osborne, J. E., Hutchinson, P. E., and Pringle, J. H. (2007). In silico analysis of the 5' region of the Vitamin D receptor gene: functional implications of evolutionary conservation. J. Steroid. Biochem. Mol. Biol. 103, 352-356. doi: 10.1016/j.jsbmb.2006.12.046

Haussler, M. R., Whitfield, G. K., Kaneko, I., Haussler, C. A., Hsieh, D., Hsieh, J. C., et al. (2013). Molecular mechanisms of vitamin D action. Calcif. Tissue Int. 92, 77-98. doi: 10.1007/s00223-012-9619-0

Hebbes, T. R., Thorne, A. W., and Crane-Robinson, C. (1988). A direct link between core histone acetylation and transcriptionally active chromatin. EMBO J. 7, 1395-1402.

Helin, K., and Dhanak, D. (2013). Chromatin proteins and modifications as drug targets. Nature 502, 480-488. doi: 10.1038/nature12751

Hendrix, I., Anderson, P., May, B., and Morris, H. (2004). Regulation of gene expression by the CYP27B1 promoter-study of a transgenic mouse model. J. Steroid Biochem. Mol. Biol. 89-90, 139-142. doi: 10.1016/j.jsbmb.2004.03.093

Herman, J. G., and Baylin, S. B. (2003). Gene silencing in cancer in association with promoter hypermethylation. N. Engl. J. Med. 349, 2042-2054. doi: 10.1056/NEJMra023075

Höbaus, J., Fetahu, I. S. H., Khorchide, M., Manhardt, T., and Kallay, E. (2013a). Epigenetic regulation of the 1,25-dihydroxyvitamin D3 24-hydroxylase (CYP24A1) in colon cancer cells. J. Steroid Biochem. Mol. Biol. 136, 296-299. doi: 10.1016/j.jsbmb.2012.08.003

Höbaus, J., Hummel, D. M., Thiem, U., Fetahu, I. S., Aggarwal, A., Müllauer, L., et al. (2013b). Increased copy-number and not DNA hypomethylation causes overexpression of the candidate proto-oncogene CYP24A1 in colorectal cancer. Int. J. Cancer 133, 1380-1388. doi: 10.1002/ijc.28143

Hobaus, J., Thiem, U., Hummel, D. M., and Kallay, E. (2013). Role of calcium, vitamin d, and the extrarenal vitamin d hydroxylases in carcinogenesis. Anticancer Agents Med. Chem. 13, 20-35. doi: 10.2174/187152013804487434

Hofman-Bang, J., Gravesen, E., Olgaard, K., and Lewin, E. (2012). Epigenetic methylation of parathyroid CaR and VDR promoters in experimental secondary hyperparathyroidism. Int. J. Nephrol. 2012:123576. doi: 10.1155/2012/123576

Iwase, S., Lan, F., Bayliss, P., De La Torre-Ubieta, L., Huarte, M., Qi, H. H., et al. (2007). The X-linked mental retardation gene SMCX/JARID1C defines a family of histone H3 lysine 4 demethylases. Cell 128, 1077-1088. doi: 10.1016/j.cell.2007.02.017

Jiang, F., Li, P., Fornace, A. J., Nicosia, S. V., and Bai, W. (2003). G2/M arrest by 1,25-dihydroxyvitamin D3 in ovarian cancer cells mediated through the induction of GADD45 via an exonic enhancer. J. Biol. Chem. 278, 48030-48040. doi: 10.1074/jbc.M308430200

Jin, B., and Robertson, K. D. (2013). DNA methyltransferases, DNA damage repair, and cancer. Adv. Exp. Med. Biol. 754, 3-29. doi: 10.1007/978-1-4419-9967-2_1

Johnson, C. S., Chung, I., and Trump, D. L. (2010). Epigenetic silencing of CYP24 in the tumor microenvironment. J. Steroid Biochem. Mol. Biol. 121, 338-342. doi: 10.1016/j.jsbmb.2010.03.046

Jones, P. A., and Baylin, S. B. (2007). The epigenomics of cancer. Cell 128, 683-692. doi: 10.1016/j.cell.2007.01.029

Jones, P. L., Veenstra, G. J., Wade, P. A., Vermaak, D., Kass, S. U., Landsberger, N., et al. (1998). Methylated DNA and MeCP2 recruit histone deacetylase to repress transcription. Nat. Genet. 19, 187-191. doi: 10.1038/561

Jung-Hynes, B., Reiter, R. J., and Ahmad, N. (2010). Sirtuins, melatonin and circadian rhythms: building a bridge between aging and cancer. J. Pineal Res. 48, 9-19. doi: 10.1111/j.1600-079X.2009.00729.x

Kahl, P., Gullotti, L., Heukamp, L. C., Wolf, S., Friedrichs, N., Vorreuther, R., et al. (2006). Androgen receptor coactivators lysine-specific histone demethylase 1 and four and a half LIM domain protein 2 predict risk of prostate cancer recurrence. Cancer Res. 66, 11341-11347. doi: 10.1158/0008-5472.CAN-06-1570

Karlic, H., and Varga, F. (2011). Impact of vitamin D metabolism on clinical epigenetics. Clin. Epigenetics 2, 55-61. doi: 10.1007/s13148-011-0021-y 
Karolchik, D., Barber, G. P., Casper, J., Clawson, H., Cline, M. S., Diekhans, M., et al. (2014). The UCSC Genome Browser database: 2014 update. Nucleic Acids Res. 42, D764-770. doi: 10.1093/nar/gkt1168

Kawashima, H., Torikai, S., and Kurokawa, K. (1981). Localization of 25-hydroxyvitamin D3 1 alpha-hydroxylase and 24-hydroxylase along the rat nephron. Proc. Natl. Acad. Sci. U.S.A. 78, 1199-1203. doi: 10.1073/pnas.78.2.1199

Khorchide, M., Lechner, D., and Cross, H. S. (2005). Epigenetic regulation of vitamin D hydroxylase expression and activity in normal and malignant human prostate cells. J. Steroid Biochem. Mol. Biol. 93, 167-172. doi: 10.1016/j.jsbmb.2004.12.022

Kim, G. D., Ni, J., Kelesoglu, N., Roberts, R. J., and Pradhan, S. (2002). Cooperation and communication between the human maintenance and de novo DNA (cytosine-5) methyltransferases. EMBO J. 21, 4183-4195. doi: 10.1093/emboj/cdf401

Kim, M. S., Fujiki, R., Kitagawa, H., and Kato, S. (2007a). lalpha,25(OH)2D3induced DNA methylation suppresses the human CYP27B1 gene. Mol. Cell Endocrinol. 265-266, 168-173. doi: 10.1016/j.mce.2006.12.014

Kim, M. S., Fujiki, R., Murayama, A., Kitagawa, H., Yamaoka, K., Yamamoto, Y., et al. (2007b). 1Alpha,25(OH)2D3-induced transrepression by vitamin D receptor through E-box-type elements in the human parathyroid hormone gene promoter. Mol. Endocrinol. 21, 334-342. doi: 10.1210/me.2006-0231

Kim, S., Li, M., Paik, H., Nephew, K., Shi, H., Kramer, R., et al. (2008). Predicting DNA methylation susceptibility using CpG flanking sequences. Pac. Symp. Biocomput. 13, 315-326.

Klose, R. J., Yamane, K., Bae, Y., Zhang, D., Erdjument-Bromage, H., Tempst, P., et al. (2006). The transcriptional repressor JHDM3A demethylates trimethyl histone H3 lysine 9 and lysine 36. Nature 442, 312-316. doi: 10.1038/nature04853

Klose, R. J., Yan, Q., Tothova, Z., Yamane, K., Erdjument-Bromage, H., Tempst, P., et al. (2007). The retinoblastoma binding protein RBP2 is an H3K4 demethylase. Cell 128, 889-900. doi: 10.1016/j.cell.2007.02.013

Kouzarides, T. (2007). Chromatin modifications and their function. Cell 128, 693-705. doi: 10.1016/j.cell.2007.02.005

Kriaucionis, S., and Heintz, N. (2009). The nuclear DNA base 5hydroxymethylcytosine is present in Purkinje neurons and the brain. Science 324, 929-930. doi: 10.1126/science.1169786

Lagger, G., Doetzlhofer, A., Schuettengruber, B., Haidweger, E., Simboeck, E., Tischler, J., et al. (2003). The tumor suppressor p53 and histone deacetylase 1 are antagonistic regulators of the cyclin-dependent kinase inhibitor p21/WAF1/CIP1 gene. Mol. Cell Biol. 23, 2669-2679. doi: 10.1128/MCB.23.8.2669-2679.2003

Lee, J. W., Lee, Y. C., Na, S. Y., Jung, D. J., and Lee, S. K. (2001). Transcriptional coregulators of the nuclear receptor superfamily: coactivators and corepressors. Cell Mol. Life Sci. 58, 289-297. doi: 10.1007/PL00000856

Lewin, E., Garfia, B., Recio, F. L., Rodriguez, M., and Olgaard, K. (2002). Persistent downregulation of calcium-sensing receptor mRNA in rat parathyroids when severe secondary hyperparathyroidism is reversed by an isogenic kidney transplantation. J. Am. Soc. Nephrol. 13, 2110-2116. doi: 10.1097/01.ASN.0000024439.38838.03

Liau, J. Y., Liao, S. L., Hsiao, C. H., Lin, M. C., Chang, H. C., and Kuo, K. T. (2014). Hypermethylation of the CDKN2A gene promoter is a frequent epigenetic change in periocular sebaceous carcinoma and is associated with younger patient age. Hum Pathol. 45, 533-539. doi: 10.1016/j.humpath.2013.10.019

Lin, C. H., Li, B., Swanson, S., Zhang, Y., Florens, L., Washburn, M. P., et al. (2008). Heterochromatin protein la stimulates histone H3 lysine 36 demethylation by the Drosophila KDM4A demethylase. Mol. Cell 32, 696-706. doi: 10.1016/j.molcel.2008.11.008

Lin, Y. W., Ren, L. L., Xiong, H., Du, W., Yu, Y. N., Sun, T. T., et al. (2013). Role of STAT3 and vitamin D receptor in EZH2-mediated invasion of human colorectal cancer. J. Pathol. 230, 277-290. doi: 10.1002/path.4179

Longo, V. D., and Kennedy, B. K. (2006). Sirtuins in aging and age-related disease. Cell 126, 257-268. doi: 10.1016/j.cell.2006.07.002

Lopes, N., Carvalho, J., Duraes, C., Sousa, B., Gomes, M., Costa, J. L., et al. (2012). 1Alpha,25-dihydroxyvitamin D3 induces de novo E-cadherin expression in triple-negative breast cancer cells by CDH1-promoter demethylation. Anticancer Res. 32, 249-257.

Lu, P. J., Sundquist, K., Baeckstrom, D., Poulsom, R., Hanby, A., Meier-Ewert, S., et al. (1999). A novel gene (PLU-1) containing highly conserved putative
DNA/chromatin binding motifs is specifically up-regulated in breast cancer. J. Biol. Chem. 274, 15633-15645. doi: 10.1074/jbc.274.22.15633

Luo, W., Karpf, A. R., Deeb, K. K., Muindi, J. R., Morrison, C. D., Johnson, C. S., et al. (2010). Epigenetic regulation of vitamin D 24-hydroxylase/CYP24A1 in human prostate cancer. Cancer Res. 70, 5953-5962. doi: 10.1158/00085472.CAN-10-0617

Marik, R., Fackler, M., Gabrielson, E., Zeiger, M. A., Sukumar, S., Stearns, V., et al. (2010). DNA methylation-related vitamin D receptor insensitivity in breast cancer. Cancer Biol. Ther. 10, 44-53. doi: 10.4161/cbt.10.1.11994

Marks, P., Rifkind, R. A., Richon, V. M., Breslow, R., Miller, T., and Kelly, W. K. (2001). Histone deacetylases and cancer: causes and therapies. Nat. Rev. Cancer 1, 194-202. doi: 10.1038/35106079

Meissner, A., Mikkelsen, T. S., Gu, H., Wernig, M., Hanna, J., Sivachenko, A., et al. (2008). Genome-scale DNA methylation maps of pluripotent and differentiated cells. Nature 454, 766-770. doi: 10.1038/nature07107

Metzger, E., Wissmann, M., Yin, N., Müller, J. M., Schneider, R., Peters, A H., et al. (2005). LSD1 demethylates repressive histone marks to promote androgen-receptor-dependent transcription. Nature 437, 436-439. doi: 10.1038/nature04020

Meyer, M. B., Benkusky, N. A., and Pike, J. W. (2013). 1,25-Dihydroxyvitamin D3 induced histone profiles guide discovery of VDR action sites. J. Steroid Biochem. Mol. Biol. doi: 10.1016/j.jsbmb.2013.09.005. [Epub ahead of print].

Miller, C. W., Morosetti, R., Campbell, M. J., Mendoza, S., and Koeffler, H. P. (1997). Integrity of the 1,25-dihydroxyvitamin D3 receptor in bone, lung, and other cancers. Mol. Carcinog. 19, 254-257. doi: 10.1002/(SICI)10982744(199708) 19:4<254::AID-MC6>3.0.CO;2-C

Mosammaparast, N., and Shi, Y. (2010). Reversal of histone methylation: biochemical and molecular mechanisms of histone demethylases. Annu. Rev. Biochem. 79, 155-179. doi: 10.1146/annurev.biochem.78.070907.103946

Mottet, D., Pirotte, S., Lamour, V., Hagedorn, M., Javerzat, S., Bikfalvi, A., et al. (2009). HDAC4 represses p21(WAF1/Cip1) expression in human cancer cells through a Sp1-dependent, p53-independent mechanism. Oncogene 28, 243-256. doi: 10.1038/onc.2008.371

Murayama, A., Kim, M. S., Yanagisawa, J., Takeyama, K., and Kato, S. (2004). Transrepression by a liganded nuclear receptor via a bHLH activator through co-regulator switching. EMBO J. 23, 1598-1608. doi: 10.1038/sj.emboj. 7600157

Nagpal, S., Na, S., and Rathnachalam, R. (2005). Noncalcemic actions of vitamin D receptor ligands. Endocr. Rev. 26, 662-687. doi: 10.1210/er.2004-0002

Nan, X., Ng, H. H., Johnson, C. A., Laherty, C. D., Turner, B. M., Eisenman, R. N., et al. (1998). Transcriptional repression by the methyl-CpG-binding protein MeCP2 involves a histone deacetylase complex. Nature 393, 386-389. doi $10.1038 / 30764$

Norman, A. W., and Bouillon, R. (2010). Vitamin D nutritional policy needs a vision for the future. Exp. Biol. Med. (Maywood) 235, 1034-1045. doi: 10.1258/ebm.2010.010014

Novakovic, B., Sibson, M., Ng, H. K., Manuelpillai, U., Rakyan, V., Down, T., et al. (2009). Placenta-specific methylation of the vitamin D 24-hydroxylase gene: implications for feedback autoregulation of active vitamin D levels at the fetomaternal interface. J. Biol. Chem. 284, 14838-14848. doi: 10.1074/jbc.M809542200

Ohyama, Y., Kusada, T., Yamasaki, T., and Ide, H. (2002). Extensive methylation of CpG island of CYP24 gene in osteoblastic ROS17/2.8 cells. Nucleic Acids Res. Suppl. 249-250. doi: 10.1093/nass/2.1.249

Okano, M., Bell, D. W., Haber, D. A., and Li, E. (1999). DNA methyltransferases Dnmt3a and Dnmt3b are essential for de novo methylation and mammalian development. Cell 99, 247-257. doi: 10.1016/S0092-8674(00)81656-6

Okano, M., Xie, S., and Li, E. (1998). Cloning and characterization of a family of novel mammalian DNA (cytosine-5) methyltransferases. Nat. Genet. 19, 219-220. doi: 10.1038/890

Padi, S. K., Zhang, Q., Rustum, Y. M., Morrison, C., and Guo, B. (2013). MicroRNA-627 mediates the epigenetic mechanisms of vitamin D to suppress proliferation of human colorectal cancer cells and growth of xenograft tumors in mice. Gastroenterology 145, 437-446. doi: 10.1053/j.gastro.2013. 04.012

Pan, L., Matloob, A. F., Du, J., Pan, H., Dong, Z., Zhao, J., et al. (2010). Vitamin $\mathrm{D}$ stimulates apoptosis in gastric cancer cells in synergy with trichostatin A /sodium butyrate-induced and 5-aza-2'-deoxycytidine-induced PTEN upregulation. FEBS J. 277, 989-999. doi: 10.1111/j.1742-4658.2009.07542.x 
Parbin, S., Kar, S., Shilpi, A., Sengupta, D., Deb, M., Rath, S. K., et al. (2014). Histone deacetylases: a saga of perturbed acetylation homeostasis in cancer. J. Histochem. Cytochem. 62, 11-33. doi: 10.1369/0022155413506582

Pedersen, J. I., Shobaki, H. H., Holmberg, I., Bergseth, S., and Björkhem, I. (1983). 25-Hydroxyvitamin D3-24-hydroxylase in rat kidney mitochondria. J. Biol. Chem. 258, 742-746.

Pedersen, M. T., and Helin, K. (2010). Histone demethylases in development and disease. Trends Cell Biol. 20, 662-671. doi: 10.1016/j.tcb.2010.08.011

Pendas-Franco, N., Aguilera, O., Pereira, F., Gonzalez-Sancho, J. M., and Munoz, A. (2008). Vitamin D and Wnt/beta-catenin pathway in colon cancer: role and regulation of DICKKOPF genes. Anticancer Res. 28, 2613-2623.

Pereira, F., Barbachano, A., Silva, J., Bonilla, F., Campbell, M. J., Munoz, A., et al. (2011). KDM6B/JMJD3 histone demethylase is induced by vitamin D and modulates its effects in colon cancer cells. Hum. Mol. Genet. 20, 4655-4665. doi: $10.1093 / \mathrm{hmg} / \mathrm{ddr} 399$

Pereira, F., Barbachano, A., Singh, P. K., Campbell, M. J., Munoz, A., and Larriba, M. J. (2012). Vitamin D has wide regulatory effects on histone demethylase genes. Cell Cycle 11, 1081-1089. doi: 10.4161/cc.11.6.19508

Perillo, B., Ombra, M. N., Bertoni, A., Cuozzo, C., Sacchetti, S., Sasso, A., et al. (2008). DNA oxidation as triggered by H3K9me2 demethylation drives estrogen-induced gene expression. Science 319, 202-206. doi: 10.1126/science. 1147674

Pfau, R., Tzatsos, A., Kampranis, S. C., Serebrennikova, O. B., Bear, S. E., and Tsichlis, P. N. (2008). Members of a family of JmjC domain-containing oncoproteins immortalize embryonic fibroblasts via a JmjC domain-dependent process. Proc. Natl. Acad. Sci. U.SA. 105, 1907-1912. doi: 10.1073/pnas.0711865105

Pike, J. W., and Meyer, M. B. (2013). Fundamentals of vitamin D hormoneregulated gene expression. J. Steroid Biochem. Mol. Biol. doi: 10.1016/j.jsbmb. 2013.11.004. [Epub ahead of print].

Pike, J. W., Meyer, M. B., and Bishop, K. A. (2012). Regulation of target gene expression by the vitamin D receptor - an update on mechanisms. Rev. Endocr. Metab. Disord. 13, 45-55. doi: 10.1007/s11154-011-9198-9

Polly, P., Herdick, M., Moehren, U., Baniahmad, A., Heinzel, T., and Carlberg, C. (2000). VDR-Alien: a novel, DNA-selective vitamin D(3) receptor-corepressor partnership. FASEB J. 14, 1455-1463. doi: 10.1096/fj.14.10.1455

Rashid, S. F., Moore, J. S., Walker, E., Driver, P. M., Engel, J., Edwards, C. E., et al. (2001). Synergistic growth inhibition of prostate cancer cells by 1 alpha, 25 Dihydroxyvitamin $\mathrm{D}(3)$ and its 19-nor-hexafluoride analogs in combination with either sodium butyrate or trichostatin A. Oncogene 20, 1860-1872. doi: 10.1038/sj.onc. 1204269

Rawson, J. B., Sun, Z., Dicks, E., Daftary, D., Parfrey, P. S., Green, R. C., et al. (2012). Vitamin D intake is negatively associated with promoter methylation of the Wnt antagonist gene DKK1 in a large group of colorectal cancer patients. Nutr. Cancer 64, 919-928. doi: 10.1080/01635581.2012.711418

Reik, W., and Lewis, A. (2005). Co-evolution of X-chromosome inactivation and imprinting in mammals. Nat. Rev. Genet. 6, 403-410. doi: 10.1038/nrg1602

Rhee, I., Bachman, K. E., Park, B. H., Jair, K. W., Yen, R. W., Schuebel, K. E., et al. (2002). DNMT1 and DNMT3b cooperate to silence genes in human cancer cells. Nature 416, 552-556. doi: 10.1038/416552a

Rhee, I., Jair, K. W., Yen, R. W., Lengauer, C., Herman, J. G., Kinzler, K. W., et al. (2000). CpG methylation is maintained in human cancer cells lacking DNMT1. Nature 404, 1003-1007. doi: 10.1038/35010000

Robertson, K. D. (2005). DNA methylation and human disease. Nat. Rev. Genet. 6, 597-610. doi: 10.1038/nrg1655

Saito, Y., Liang, G., Egger, G., Friedman, J. M., Chuang, J. C., Coetzee, G. A., et al. (2006). Specific activation of microRNA-127 with downregulation of the protooncogene BCL6 by chromatin-modifying drugs in human cancer cells. Cancer Cell 9, 435-443. doi: 10.1016/j.ccr.2006.04.020

Sakai, T., Toguchida, J., Ohtani, N., Yandell, D. W., Rapaport, J. M., and Dryja, T. P. (1991). Allele-specific hypermethylation of the retinoblastoma tumorsuppressor gene. Am. J. Hum. Genet. 48, 880-888.

Sakaki, T., Sawada, N., Komai, K., Shiozawa, S., Yamada, S., Yamamoto, K., et al. (2000). Dual metabolic pathway of 25-hydroxyvitamin D3 catalyzed by human CYP24. Eur. J. Biochem. 267, 6158-6165. doi: 10.1046/j.1432-1327.2000.01680.x

Saramäki, A., Diermeier, S., Kellner, R., Laitinen, H., Vaïsänen, S., and Carlberg, C. (2009). Cyclical chromatin looping and transcription factor association on the regulatory regions of the p21 (CDKN1A) gene in response to lalpha,25-dihydroxyvitamin D3. J. Biol. Chem. 284, 8073-8082. doi: 10.1074/jbc.M808090200
Schulte, J. H., Lim, S., Schramm, A., Friedrichs, N., Koster, J., Versteeg, R., et al. (2009). Lysine-specific demethylase 1 is strongly expressed in poorly differentiated neuroblastoma: implications for therapy. Cancer Res. 69, 2065-2071. doi: 10.1158/0008-5472.CAN-08-1735

Schwer, B., and Verdin, E. (2008). Conserved metabolic regulatory functions of sirtuins. Cell Metab. 7, 104-112. doi: 10.1016/j.cmet.2007.11.006

Seuter, S., Pehkonen, P., Heikkinen, S., and Carlberg, C. (2013). Dynamics of $1 \alpha, 25$-dihydroxyvitamin D3-dependent chromatin accessibility of early vitamin D receptor target genes. Biochim. Biophys. Acta 1829, 1266-1275. doi: 10.1016/j.bbagrm.2013.10.003

Shi, H., Guo, J., Duff, D. J., Rahmatpanah, F., Chitima-Matsiga, R., Al-Kuhlani, M., et al. (2007). Discovery of novel epigenetic markers in non-Hodgkin's lymphoma. Carcinogenesis 28, 60-70. doi: 10.1093/carcin/bgl092

Shi, H., Yan, P. S., Chen, C. M., Rahmatpanah, F., Lofton-Day, C., Caldwell, C. W., et al. (2002). Expressed CpG island sequence tag microarray for dual screening of DNA hypermethylation and gene silencing in cancer cells. Cancer Res. 62, 3214-3220.

Shi, Y., Lan, F., Matson, C., Mulligan, P., Whetstine, J. R., Cole, P. A., et al. (2004). Histone demethylation mediated by the nuclear amine oxidase homolog LSD1. Cell 119, 941-953. doi: 10.1016/j.cell.2004.12.012

Shi, Y., and Whetstine, J. R. (2007). Dynamic regulation of histone lysine methylation by demethylases. Mol. Cell 25, 1-14. doi: 10.1016/j.molcel.2006.12.010

Singh, P. K., Doig, C. L., Dhiman, V. K., Turner, B. M., Smiraglia, D. J., and Campbell, M. J. (2013). Epigenetic distortion to VDR transcriptional regulation in prostate cancer cells. J. Steroid Biochem. Mol. Biol. 136, 258-263. doi: 10.1016/j.jsbmb.2012.10.002

Sulaiman, L., Juhlin, C. C., Nilsson, I. L., Fotouhi, O., Larsson, C., and Hashemi, J. (2013). Global and gene-specific promoter methylation analysis in primary hyperparathyroidism. Epigenetics 8, 646-655. doi: 10.4161/epi.24823

Tahiliani, M., Mei, P., Fang, R., Leonor, T., Rutenberg, M., Shimizu, F., et al. (2007). The histone H3K4 demethylase SMCX links REST target genes to X-linked mental retardation. Nature 447, 601-605. doi: 10.1038/nature05823

Takeyama, K., and Kato, S. (2011). The vitamin D3 lalpha-hydroxylase gene and its regulation by active vitamin D3. Biosci. Biotechnol. Biochem. 75, 208-213. doi: 10.1271/bbb. 100684

Tan, J., Lu, J., Huang, W., Dong, Z., Kong, C., Li, L., et al. (2009). Genomewide analysis of histone $\mathrm{H} 3$ lysine9 modifications in human mesenchymal stem cell osteogenic differentiation. PLoS ONE 4:e6792. doi: 10.1371/journal.pone.0006792

Tapp, H. S., Commane, D. M., Bradburn, D. M., Arasaradnam, R., Mathers, J. C., Johnson, I. T., et al. (2013). Nutritional factors and gender influence age-related DNA methylation in the human rectal mucosa. Aging Cell 12, 148-155. doi: 10.1111/acel.12030

Ting, A. H., McGarvey, K. M., and Baylin, S. B. (2006). The cancer epigenomecomponents and functional correlates. Genes Dev. 20, 3215-3231. doi: 10.1101/gad.1464906

Tsai, H. C., and Baylin, S. B. (2011). Cancer epigenetics: linking basic biology to clinical medicine. Cell Res. 21, 502-517. doi: 10.1038/cr.2011.24

Tsukada, Y., Fang, J., Erdjument-Bromage, H., Warren, M. E., Borchers, C. H., Tempst, P., et al. (2006). Histone demethylation by a family of JmjC domaincontaining proteins. Nature 439, 811-816. doi: 10.1038/nature04433

Vanoirbeek, E., Eelen, G., Verlinden, L., Carmeliet, G., Mathieu, C., Bouillon, R., et al. (2014). PDLIM2 expression is driven by vitamin D and is involved in the pro-adhesion, and anti-migration and -invasion activity of vitamin D. Oncogene 33, 1904-1911. doi: 10.1038/onc.2013.123

Varshney, S., Bhadada, S. K., Sachdeva, N., Arya, A. K., Saikia, U. N., Behera, A., et al. (2013). Methylation status of the CpG islands in vitamin D and calciumsensing receptor gene promoters does not explain the reduced gene expressions in parathyroid adenomas. J. Clin. Endocrinol. Metab. 98, E1631-E1635. doi: 10.1210/jc.2013-1699

Von Essen, M. R., Kongsbak, M., Schjerling, P., Olgaard, K., Odum, N., and Geisler, C. (2010). Vitamin D controls T cell antigen receptor signaling and activation of human T cells. Nat. Immunol. 11, 344-349. doi: 10.1038/ni.1851

Wang, Y., and Leung, F. C. (2004). An evaluation of new criteria for CpG islands in the human genome as gene markers. Bioinformatics 20, 1170-1177. doi: 10.1093/bioinformatics/bth059

Whetstine, J. R., Nottke, A., Lan, F., Huarte, M., Smolikov, S., Chen, Z., et al. (2006). Reversal of histone lysine trimethylation by the JMJD2 family of histone demethylases. Cell 125, 467-481. doi: 10.1016/j.cell.2006.03.028 
Williams, K., Christensen, J., Pedersen, M. T., Johansen, J. V., Cloos, P. A., Rappsilber, J., et al. (2011). TET1 and hydroxymethylcytosine in transcription and DNA methylation fidelity. Nature 473, 343-348. doi: 10.1038/nature 10066

Wilson, A. J., Byun, D. S., Popova, N., Murray, L. B., L’Italien, K., Sowa, Y., et al. (2006). Histone deacetylase 3 (HDAC3) and other class I HDACs regulate colon cell maturation and p21 expression and are deregulated in human colon cancer. J. Biol. Chem. 281, 13548-13558. doi: 10.1074/jbc.M5100 23200

Wjst, M., Heimbeck, I., Kutschke, D., and Pukelsheim, K. (2010). Epigenetic regulation of vitamin D converting enzymes. J. Steroid Biochem. Mol. Biol. 121, 80-83. doi: 10.1016/j.jsbmb.2010.03.056

Xiang, Y., Zhu, Z., Han, G., Ye, X., Xu, B., Peng, Z., et al. (2007). JARID1B is a histone H3 lysine 4 demethylase up-regulated in prostate cancer. Proc. Natl. Acad. Sci. U.S.A. 104, 19226-19231. doi: 10.1073/pnas.0700735104

Yamaguchi, S., Hong, K., Liu, R., Shen, L., Inoue, A., Diep, D., et al. (2012). Tet1 controls meiosis by regulating meiotic gene expression. Nature 492, 443-447. doi: 10.1038/nature11709

Yamane, K., Tateishi, K., Klose, R. J., Fang, J., Fabrizio, L. A., Erdjument-Bromage, H., et al. (2007). PLU-1 is an H3K4 demethylase involved in transcriptional repression and breast cancer cell proliferation. Mol. Cell 25, 801-812. doi: 10.1016/j.molcel.2007.03.001

Yamshchikov, A. V., Desai, N. S., Blumberg, H. M., Ziegler, T. R., and Tangpricha, V. (2009). Vitamin D for treatment and prevention of infectious diseases: a systematic review of randomized controlled trials. Endocr. Pract. 15, 438-449. doi: 10.4158/EP09101.ORR

Yoneda, T., Aya, S., and Sakuda, M. (1984). Sodium butyrate (SB) augments the effects of 1,25 dihydroxyvitamin D3 $(1,25(\mathrm{OH}) 2 \mathrm{D} 3)$ on neoplastic and osteoblastic phenotype in clonal rat osteosarcoma cells. Biochem. Biophys. Res. Commun. 121, 796-801. doi: 10.1016/0006-291X(84)90748-4
Zhang, X., Nicosia, S. V., and Bai, W. (2006). Vitamin D receptor is a novel drug target for ovarian cancer treatment. Curr. Cancer Drug. Targets 6, 229-244. doi: $10.2174 / 156800906776842939$

Zhang, Z., Yamashita, H., Toyama, T., Sugiura, H., Ando, Y., Mita, K., et al. (2005). Quantitation of HDAC1 mRNA expression in invasive carcinoma of the breast*. Breast Cancer Res. Treat. 94, 11-16. doi: 10.1007/s10549-005-6001-1

Zhu, H., Wang, X., Shi, H., Su, S., Harshfield, G. A., Gutin, B., et al. (2013). A genome-wide methylation study of severe vitamin D deficiency in African American adolescents. J. Pediatr. 162, 1004-1009.e1001. doi: 10.1016/j.jpeds.2012.10.059

Zhu, P., Martin, E., Mengwasser, J., Schlag, P., Janssen, K. P., and Göttlicher, M. (2004). Induction of HDAC2 expression upon loss of APC in colorectal tumorigenesis. Cancer Cell 5, 455-463. doi: 10.1016/S1535-6108(04)00114-X

Conflict of Interest Statement: The authors declare that the research was conducted in the absence of any commercial or financial relationships that could be construed as a potential conflict of interest.

Received: 09 February 2014; paper pending published: 07 March 2014; accepted: 09 April 2014; published online: 29 April 2014.

Citation: Fetahu IS, Höbaus J and Kállay E (2014) Vitamin D and the epigenome. Front. Physiol. 5:164. doi: 10.3389/fphys.2014.00164

This article was submitted to Integrative Physiology, a section of the journal Frontiers in Physiology.

Copyright (c) 2014 Fetahu, Höbaus and Kállay. This is an open-access article distributed under the terms of the Creative Commons Attribution License (CC BY). The use, distribution or reproduction in other forums is permitted, provided the original author(s) or licensor are credited and that the original publication in this journal is cited, in accordance with accepted academic practice. No use, distribution or reproduction is permitted which does not comply with these terms. 